УДК 378.016:373.2.011.3 - 051

DOI: $10.35619 /$ iiu.v1i10.163

Горопаха Наталія

кандидат педагогічних наук, доцент, доцент кафедри педагогіки і психології (дошкільної та корекційної) імені проф. Т.І. Поніманської Рівненського державного гуманітарного університету, м.Рівне, Україна ORCID 0000-0002-5406-1963 e-mail: natagor62@gmail.com

\title{
ПІДГОТОВКА МАЙБУТНІХ ВИХОВАТЕЛІВ ДОШКІЛЬНИХ ЗАКЛАДІВ ТА ЛОГОПЕДІВ ДО ВИЯВЛЕННЯ І РОЗВИТКУ ОБДАРОВАНИХ ДІТЕЙ
}

Анотація. У статті розглядається проблема підготовки майбутніх педагогів (вихователів закладів дошкільної освіти та логопедів) до роботи 3 обдарованими дітьми, обгрунтовуються ефективні форми та методи роботи зі студентами у процесі викладання навчальної дисципліни «Виховання обдарованих дітей». Особлива увага звертається на проблему пошуку обдарованих дітей серед таких категорій дітей, які інколи називають особливими: дітей з вадами сенсорного чи фізичного розвитку, 3 затримками мовленнєвого розвитку тощо. Автор доводить, що готовність вихователя чи логопеда працювати 3 обдарованими дітьми визначається наявністю у нього теоретичних знань і практичного досвіду, які формують особливу особистісну позицію дорослого у ставленні до обдарованої дитини. Педагог, який працює з інтелектуально обдарованими дітьми, повинен мати професійні та особистісні якості, такі як позитивна Я-концепція, впевненість у собі, зрілість та емоційна стійкість, розвинутий інтелект та широкі інтереси, нетрадиційна особиста ідеологія тощо. Автор стверджує, що основною педагогічною умовою підготовки майбутніх вихователів та логопедів до роботи 3 обдарованими дошкільниками $\epsilon$ використання інтерактивних методів навчання у закладі вищої освіти. Описано приклади використання інтерактивних методів під час лекцій та практичних занять. Також у статті аналізуються деякі концепції обдарованості, з якими варто ознайомитися майбутнім вихователям.

Ключові слова: обдарованість, обдарована дитина, вихователь закладу дошкільної освіти, логопед, Я-концепція, інтерактивні методи навчання, лекція, взаємонавчання.

Постановка проблеми. Розробка нових концепцій дошкільної освіти, які грунтуються на принципах самоцінності дошкільного дитинства як важливого етапу в житті та розвитку дитини, гуманізації всього процесу суспільного та сімейного виховання дошкільнят серед іншого актуалізує й проблему раннього вияву обдарованості дитини. Одним із головних завдань закладу дошкільної освіти $\epsilon$ створення умов для всебічного розвитку особистості кожної дитини, розкриття іiі індивідуальності, забезпечення емоційного та фізичного благополуччя. Розв'язання цього завдання передбачає, як один із аспектів, - створення умов для раннього виявлення та розвитку здібностей та обдарувань дітей. Психологічні дослідження доводять, що обдарованість, як складне психологічне явище, невіддільна від цілісної особистості, розвивається протягом життя, тому іiї вивчення повинно проводитися на різних стадіях онтогенезу, починаючи з раннього та дошкільного дитинства (Лейтес, 1996). Водночас багато авторів вказують на виключно важливе значення саме перших років життя дитини для розвитку ії обдарованості та творчості (П. Торренс, Г. Доман, Л. Венгер, О. Матюшкін, О. Савенков тощо).

Поглиблення наукових уявлень про сутність обдарованості та ії̈ прояви на різних етапах життя людини привертають увагу до різних аспектів проблеми, які ще донедавна сприймалися як парадоксальні. Йдеться про пошук обдарованих серед таких 
категорій дітей, яких інколи називають особливими (Лейтес, 1996, с. 104): дітей 3 вадами сенсорного чи фізичного розвитку, з затримками мовленнєвого розвитку тощо. I хоча проблема діагностики та розвитку обдарованості серед дітей цих категорій поки що не отримала грунтовного дослідження, певний практичний досвід у цій галузі, накопичений у країнах, де діють кілька спеціальних програм для обдарованих дітей 3 вадами розвитку (США) (Шведел та Стоунбернер, 1991), переконує у своєчасності іiі постановки. На жаль, нашому суспільству притаманне певне стереотипне сприйняття дитини з вадами розвитку (у тому числі і з логопедичними проблемами), при якому наявний у неї недолік стає немов би всеохоплюючим, затуляє всі інші особливості дитини, що, безумовно, не дозволяє побачити у цій дитині жодних ознак обдарованості.

Аналіз проблеми виховання та навчання обдарованих дошкільнят підводить до висновку, що результативність цього процесу значною мірою залежить від ставлення дорослих (батьків, вихователів закладів дошкільної освіти тощо) до дітей, прийняття їх такими, як вони $\epsilon$. Тому чи не найважливішою умовою ефективності цієї роботи $\epsilon$ готовність педагогів бути вихователем, учителем обдарованої дитини. I це однаково стосується і фахівців у галузі спеціальної освіти (логопедів, дефектологів), і педагогів закладів дошкільної освіти. Водночас, процес професійного становлення вихователя здібних дітей, сам образ такого педагога, на жаль, залишається на другому плані теоретиків та практиків, увага яких приділена у більшості самій обдарованій дитині.

Аналіз останніх досліджень 3 проблеми. Для успіху діяльності, спрямованої на виявлення, підтримку та розвиток дитячої обдарованості, педагог повинен володіти цілим комплексом професійних та особистісних якостей, які складають основу його психологічної та професійної готовності до цієї роботи. На думку В. Слуцького, основою готовності до роботи 3 обдарованими дітьми $\epsilon$ наявність у педагога низки особистісних та професійних якостей, зокрема чуйності та доброзичливості, високого рівня власного інтелектуального розвитку, динамічного характеру та почуття гумору. Важливі також позитивна Я-концепція, впевненість у собі, зрілість та емоційна стабільність, які допомагають вихователю уникнути багатьох негативних випадків у налагодженні взаємин із обдарованими вихованцями (Бурменська та Слуцький, 1991, c. 10).

Американські фахівці в галузі підготовки кадрів для навчання обдарованих дітей наголошують, що основу психологічної готовності педагога до роботи з обдарованими вихованцями складають, у першу чергу, особистісні якості педагога (Карне, 1991). Зокрема, в пропонованій ними програмі «Astor» для інтелектуально обдарованих дітей дошкільного та молодшого шкільного віку наголошується на таких важливих для педагога, який працює з обдарованими, якостях, як бути доброзичливим і чутливим, орієнтуватися в особливостях психології обдарованих дітей, відчувати їхні потреби та інтереси; мати високий рівень інтелектуального розвитку, широке коло інтересів і умінь; бути готовим до виконання найрізноманітніших обов'язків, пов'язаних 3 навчанням обдарованих дітей; мати живий і активний характер, володіти почуттям гумору (але без схильності до сарказму); мати творчий, можливо нетрадиційний особистісний світогляд, проявляти гнучкість, бути готовим до перегляду своїх поглядів і постійного самовдосконалення; володіти хорошим здоров'ям і життєвою стійкістю. Доцільно також мати досвід роботи у закладах для дітей молодшого шкільного чи дошкільного віку (в тому числі важливий і досвід виховання власних дітей). Не зайвим було б, окрім педагогічної, мати ще й іншу освіту та спеціальну післявишівську підготовку до роботи 3 обдарованими дітьми, бути готовим до подальшого набуття спеціальних знань (Карне, 1991, сс. 236-237).

Проте важливими є й професійні уміння. Зокрема:

1) уміння будувати навчання відповідно до результатів діагностичного обстеження дитини;

2) уміння модифікувати навчальні програми; 
3) уміння стимулювати когнітивні здібності учнів;

4) уміння працювати за спеціальним навчальним планом;

5) уміння консультувати вихованців, їхніх батьків (Карне, 1991, с. 242).

Психологічні аспекти готовності вихователів закладів дошкільної освіти до роботи 3 обдарованим дітьми досліджує Н. Довгань. У структурі готовності вона виділяє кілька складових, зокрема, мотиваційну (групи мотивів, що активізують вихователів до роботи 3 обдарованими дітьми), когнітивну (комплекс знань щодо психологічних особливостей обдарованих дітей та особливостей роботи 3 ними), операційнорегулятивну (комплекс умінь і навичок, необхідних для ефективної роботи вихователів 3 обдарованими дітьми) та особистісну (сукупність індивідуально-особистісних якостей вихователя, необхідних для ефективної роботи з обдарованими дітьми). Вчена також наголошує на важливості розвитку у вихователів мотивації до підтримки обдарування в кожній дитині, актуалізації особистісних характеристик вихователів, які забезпечують ефективну навчально-виховну взаємодію 3 обдарованими дітьми, та сприяння самопізнанню $\mathrm{i}$ самоприйняттю власної особистості як вихователя обдарованих дітей (Довгань, 2013).

О. Кононко (2008) підкреслює, що для педагога, який працює 3 інтелектуально обдарованими дітьми, важливими професійними та особистісними якостями $\epsilon$ неупередженість, творчий, нетрадиційний особистий світогляд, знання обдарованої дитини, іiї потреб та інтересів, розвинений інтелект та широкі інтереси, емоційна стабільність, врівноваженість, гнучкість, динамічність поведінки, здатність переглядати свої погляди, самовдосконалюватися; почуття гумору, здатність ставитися до дитини не лише як до носія обдарованості, а як до особистості з їі сильними та слабкими сторонами тощо.

Отже, аналіз наукових джерел підтверджує, що, якщо питань формування у вихователів готовності до пошуку, виявлення та підтримки обдарованих дітей у дошкільному віці торкаються чимало авторів, то питання готовності доконче фахівців спеціальної освіти (серед них логопедів) до такої психолого-педагогічної діяльності не досліджується. Проте, можемо відзначити, що багато 3 перелічених якостей $\epsilon$, на думку дослідників, важливими елементами професійної компетентності вчителялогопеда. Зокрема, як підкреслює Л. Федорович, компетентний логопед характеризується тим, що він має не тільки професійні знання, уміння та навички, а може приймати відповідальні рішення в ситуаціях вибору, схильний до співробітництва, вирізняється мобільністю, динамізмом, конструктивністю, завжди саморозвивається та виходить за межі своєї дисципліни (Федорович, 2011). Більше того, як зауважують американські дослідники, саме у педагогів, підготовлених для роботи $з$ дітьми, що мають особливі освітні потреби, є суттєва перевага - вони вміють здійснювати диференційоване навчання та складати індивідуальні навчальні програми (Карне, 1991). Крім того, саме завдяки їхньому корекційному впливу, унаслідок якого недоліки дитини певною мірою компенсуються чи пом'якшуються, може проявитися дійсна обдарованість такої дитини.

Мета статті: розкрити особливості підготовки майбутніх вихователів закладів дошкільної освіти та логопедів до роботи з обдарованими дітьми.

Виклад основного матеріалу дослідження. Готовність педагога працювати 3 обдарованими дітьми визначається наявністю у нього теоретичних знань і практичного досвіду, які лягли б в основу особливої особистісної позиції у ставленні до обдарованої дитини. Її складають власна позитивна Я-концепція; прийняття обдарованої дитини такою як вона $\epsilon$, любов та доброзичливе ставлення до неї; налаштованість на пізнавальне спілкування і співробітництво з дитиною; підтримка та розвиток інтересів дитини до пізнання різноманітних сторін навколишньої дійсності; відкритість до будьяких форм дитячої творчості. Ця особистісна позиція закладається саме у період професійного становлення педагога, набуття ним фахових компетенцій, тобто у період вузівського навчання. На підготовку майбутніх вихователів ЗДО та логопедів до 
роботи 3 обдарованими дітьми спрямовується викладання навчальної дисципліни «Виховання обдарованих дітей», передбаченої освітньою програмою підготовки магістрів. Важливим завданням, що постає у процесі підготовки, $є$ закладання теоретичної основи для вироблення у завтрашніх вихователів та логопедів власного погляду на їхню роль у розвитку здібностей кожного вихованця, формування готовності до виявлення обдарованих дітей та впевненості у можливостях розвитку дитячих обдарувань в умовах навчального закладу (закладу дошкільної освіти, школи, реабілітаційного центру тощо).

Очевидно, що реалізація цього завдання вимагає нового підходу до традиційних вузівських форм навчання, зокрема, лекцій, яким необхідно придати інтерактивного характеру. Тому традиційні лекції варто замінили на мультимедійні, які забезпечують наочний супровід, тренінг-лекції, інтерактивні дискусії, уможливлять створення умови для активної участі студентів у навчальному процесі. Досить часто лекція синтезує великий обсяг знань, який у традиційному варіанті викладач подає в опрацьованому вигляді. Як правило, такі лекції мають оглядовий характер, оскільки лектор, намагаючись охопити всі аспекти чи питання теми, встигає розкрити їх поверхово, лише побіжно ознайомити слухачів з основними тезами (скажімо, історією поглядів на обдарованість як психологічний феномен, концепціями обдарованості, іiі типологією тощо). Значно цінніше побудувати лекційне заняття на основі залучення студентів до само- та взаємонавчання. Наприклад, розкриваючи сучасні концепції обдарованості, можна запропонувати студентам попередньо ознайомитися зі змістом лекції на основі тезового викладу чи схеми основних ідей, аби під час викладу матеріалу не просто описати майбутнім вихователям та логопедам найпопулярніші концепції, а спонукати слухачів до критичного сприймання інформації, власної оцінки їх з позицій свого, хай і незначного, педагогічного досвіду, здобутого, приміром, під час педагогічної практики. Зокрема, 3 аналізу праць у цій сфері студенти дізнаються, що найпопулярнішою вважається концепція відомого американського вченого Дж. Рензуллі. На його думку, обдарованість $\epsilon$ результатом поєднання трьох характеристик: інтелектуальних здібностей, що перевищують середній рівень, творчого підходу (креативності) та наполегливості (мотивації, орієнтованої на завдання). Автор відзначає: за його концепцією можна визначити значно більшу кількість обдарованих дітей, ніж під час їх ідентифікації за результатами тестів. Він не пов'язує поняття «обдарованість» лише з екстремально високими оцінками за кожним iз параметрів. Приваблює демократичність цієї моделі, що дозволяє відносити до категорії обдарованих тих, хто виявив високі показники хоча б за одним із параметрів, у тому числі й дітей, що мають логопедичні проблеми. Багато спільного $з$ моделлю Дж. Рензуллі має концепція обдарованості П. Торренса, яка складається 3 тріади: творчі здібності, уміння та мотивація. Творчість, у його розумінні, - це природний процес, породжуваний надпотребою людини у знятті напруження, що виникає в ситуації незавершеності або невизначеності (Марінушкіна та Шубіна, 2008, с. 16-19). Важливою особливістю сучасного розуміння обдарованості $\epsilon$ те, що вона розглядається не як статична, а як динамічна характеристика особистості (Савенков, 2004). Обдарованість реально існує лише в русі, у розвитку. Такий погляд на обдарованість вимагає аналізу не лише іiї ознак, а й факторів, тобто тих умов (психологічних, педагогічних, соціальних), які здатні забезпечити цей розвиток.

Лекцію також можна побудувати у формі інтерактивної дискусії. Наприклад, аналізуючи проблему вибору концептуальної моделі та основної стратегії організації роботи 3 обдарованою дитиною, лектор пропонує студентам співставити «плюси» та «мінуси» кожної 3 концептуальних моделей, приміряючи їх до реалій сучасної української школи чи дошкільного закладу, знайти аргументи, які б переконали опонентів у перевагах обраної стратегії роботи з обдарованими дошкільниками.

Оскільки для формування у майбутніх вихователів та логопедів готовності до роботи $з$ обдарованими дітьми важливо не лише навчити студентів отримувати готову 
інформацію, а й спонукати їх до самостійного пізнання, відкриття педагогічних істин, постійних творчих пошуків, деякі теми свідомо не виносяться на лекції, а пропонуються у формі колективних проектів для самостійної навчально-дослідницької роботи. Сутність методу в тому, що, розділившись на підгрупи, студенти колективно готують матеріал 3 визначеного питання, який вони мають презентувати під час практичного заняття.

Тож проілюструвати його використання для вивчення теми «Виявлення обдарованості та здібностей дітей» можна у такий спосіб. Оскільки у названій темі три основних питання (1. Принципи проведення діагностики та здібностей дітей в дошкільному закладі. 2. Методи діагностики рівня інтелектуального розвитку дитини дошкільного віку: «R. Kettle CF-test» («Культурно вільний тест Р.Кеттела») та «Raven's Progressive Matrices» («Прогресивні матриці Равена»). 3. Діагностика творчого потенціалу дитини дошкільного віку, тести креативності П. Торренса («The Minnesota Tests of Creative Thinking»), група розділяється на три підгрупи. Для презентації студенти мають підготувати доповідь з мультимедійним супроводом; зі студентами провести короткий тренінг щодо застосування діагностичних методик або інтерпретації результатів діагностики, проведеної у закладі дошкільної освіти.

Працюючи 3 цієї теми 3 майбутніми логопедами, варто їхню увагу звернути на аналіз методики виявлення обдарованих та талановитих дітей, розробленої американськими психологами університету штату Іллінойс для програми «RAPYNT» (для дітей, що мають сенсорні та фізичні недоліки) (Шведел та Стоунбернер, 1991, c. 194). При цьому важливо показати майбутнім логопедам, що розробники методики прагнули обійти традиційні процедури пошуку обдарованих дітей, орієнтуючи вчителів на визначення здібностей усіх вихованців у класі. Це дозволило вчителям виявити потенційно обдарованих дошкільнят, деякі з них мали ті чи інші порушення: дефекти слуху, затримки мовного розвитку або церебральні паралічі. Безперечно, це лише один 3 аспектів формування у майбутніх логопедів готовності до навчання i виховання обдарованої дитини, однак впевнені, що аналіз методики «RAPYHT» допоміг їм подивитися на дітей, котрі мають сенсорні або фізичні недоліки, під іншим кутом зору і переконав у необхідності розвивати здібності, наявні у цих дітей.

Розвитку творчих та педагогічних здібностей студентів сприяє також робота над мультимедійним проектом «Життя видатних дітей». Використавши самостійно дібрані матеріали, кожен студент повинен підготувати повідомлення про одного 3 діячів світової науки чи культури, чия обдарованість виявилася вже в дитячому віці. Цінність цієї форми роботи у тому, що підготовка проекту вчить аналізувати умови життя та виховання обраної особистості, визначати фактори, які найбільше вплинули на ранній вияв iї обдарованості. Захист проекту може організовуватися i як підсумкове практичне заняття чи залік, і як виступ студентів магістратури перед студентами бакалаврського рівня, скажімо, у вечірні години в студентському гуртожитку. Форма доповіді різноманітна: від традиційного академічного реферату до ліричного есе чи жартівливого вірша.

Висновки і перспективи подальших розвідок. Надзвичайно важливо, щоб 3 дітьми працювали компетентні, творчі педагоги, зацікавлені особистісним зростанням своїх вихованців, такі, що вміють створити в процесі навчання позитивну атмосферу, сприятливу для розкриття дитячих талантів. Педагогові, готовому до роботи 3 обдарованими дітьми, має бути притаманна позитивна Я-концепція (впевненість у собі), зрілість та емоційна стабільність, які допомагають уникнути багатьох негативних чинників у налагодженні взаємин із обдарованими вихованцями. Формування цих якостей у майбутніх вихователів закладів дошкільної освіти та логопедів можливе за умови використання у роботі зі студентами інтерактивних методів навчання. 
Перспективи подальших досліджень вбачаємо в пошуку шляхів формування у майбутніх вихователів та логопедів готовності до роботи з обдарованими дітьми під час педагогічної практики.

\section{СПИСОК ВИКОРИСТАНИХ ДЖЕРЕЛ}

Лейтес, Н. [ред.] (1996). Психология одарённости детей и подростков. Москва: Академия, $416 \mathrm{c}$.

Шведел, А. та Стоунбернер, Р. (1991). Поиск и выявление одарённых детей. В: Бурменская, Г.В. и Слуцкий В.М., [ред.] Одарённые дети. Перевод с англ. Д. А. Линника и А. Г. Мкервали. Москва: «Прогресс», с. 169-204.

Бурменская, Г. и Слуцкий, В., [ред.] (1991). Одарённые дети. Перевод с англ. Д. А. Линника и А. Г. Мкервали. Москва: «Прогресс», 376 с.

Карне, М. (1991) Одарённость: выявление и развитие. Глава 4. Учитель. В: Бурменская, Г. В. и Слуцкий, В. М., ред. Одарённые дети. Перевод с англ. Д. А. Линника и А.Г. Мкервали. Москва: «Прогресс», с. 235-256.

Довгань, Н. (2013). Розвиток психологічної готовності вихователів дошкільних навчальних закладів до роботи з обдарованими дітьми. Кандидат психологічних наук. Харківський національний університет ім. В. Н. Каразіна.

Кононко, О. (2008). Характеристика та особливості розвитку обдарованої дитини. В: Кононко, О. Л., ред. Базова програма розвитку дитини дошкільного віку «Я у Світі». Київ: Світич, с. 377-381.

Федорович, Л. (2011). Компетентнісний підхід у підготовці майбутнього логопеда до професійно-педагогічної діяльності. Збірник наукових праць Кам'янецьПодільського начіонального університету імені Івана Огієнка. Серія: Соціальнопедагогічна, 17(2), 325-334. [online]. Режим доступу: http://nbuv.gov.ua/UJRN/znpkp_sp_2011_17(2)_42 [Дата звернення 22.02.2019]

Марінушкіна, О. та Шубіна, Г. (2008). Родина та обдарована дитина. Харків: Вид. група «Основа», $191 \mathrm{c}$.

Савенков, А. (2004). Одаренный ребенок дома и в школе. Екатеринбург: УФактория, 246 с.

\section{REFERENCES}

Leytes. N., [red.] (1996). Psikhologiya odarennosti detey i podrostkov [Psychology of Gifted Children and Adolescents]. Moskva: Akademiya. 416 s. (in Russian)

Shvedel, A. \& Stounberner, R. (1991). Poisk i vyyavleniye odarennykh detey [Searching and Identification of Gifted Children]. V: Burmenskaya, G. V. \& Slutskiy, V. M., red. Odarennyye deti. Perevod s angl. D. A. Linnika \& A. G. Mkervali. Moskva: "Progress", s. 169-204. (in Russian)

Burmenskaya. G. \& Slutskiy. V. [red.] (1991). Odarennyye deti [Gifted Children]. Perevod s angl. D.A. Linnika \& A.G. Mkervali. Moskva: "Progress". 376 s. (in Russian)

Karne, M. (1991). Odarennost: vyyavleniye i razvitiye. Glava 4. Uchitel [Cleverness: Identification and Development. Chapter 4. The Teacher]. V: Burmenskaya, G. V. i Slutskiy, V. M., red. Odarennyye deti. Perevod s angl. D. A. Linnika \& A. G. Mkervali. Moskva: "Progress". ss. 235-256. (in Russian)

Dovhan, N. (2013). Rozvytok psykholohichnoi hotovnosti vykhovateliv doshkilnykh navchalnykh zakladiv do roboty $z$ obdarovanymy ditmy [Development of Psychological Readiness of Preschool teachers to Work with Gifted Children]. Kandydat psykholohichnykh nauk. Kharkivskyi natsionalnyi universytet im. V. N. Karazina. (in Ukrainian)

Kononko, O. (2008). Kharakterystyka ta osoblyvosti rozvytku obdarovanoi dytyny [Characteristics and Features of Development of Gifted Child]. V: Kononko, O. L., red. Bazova prohrama rozvytku dytyny doshkilnoho viku "Ia u Sviti". Kyiv: Svitych, s. 377-381. (in Ukrainian)

Fedorovych, L. (2011). Kompetentnisnyi pidkhid u pidhotovtsi maibutnoho lohopeda do profesiino-pedahohichnoi diialnosti. [Competency-based Approach to Training the Future 
Speech Terapist for Professional and Educational Work]. [online] Zbirnyk naukovykh prats Kamianets-Podilskoho natsionalnoho universytetu imeni Ivana Ohiienka. Seriia: Sotsialnopedahohichna, 17(2), 325-334. [online]. URL: http://nbuv.gov.ua/UJRN/znpkp_sp_2011_

17(2)_42 [Data ostannoho zvernennia 22.02.2019] (in Ukrainian)

Marinushkina, O. I. \& Shubina, H. (2008) Rodyna ta obdarovana dytyna [Family and Gifted Child]. Kharkiv: Vyd. hrupa "Osnova", 191 s. (in Ukrainian)

Savenkov, A. (2004). Odarennyy rebenok doma i v shkole [Gifted Child at Home and at School]. Ekaterinburg: U-Faktoriya, 246 s. (in Russian)

\title{
TRAINING OF FUTURE PRE-SCHOOL TEACHERS AND SPEECH THERAPISTS FOR THE IDENTIFICATION AND DEVELOPMENT OF GIFTED CHILDREN
}

\author{
Nataliia Horopakha \\ Candidate of Pedagogical Sciences, Associate Professor, \\ Associate Professor at the Department of Pedagogy \\ and Psychology (Preschool and Correctional) \\ named after Professor T.Ponimanska, \\ Rivne State University for the Humanities, \\ Rivne, Ukraine \\ ORCID 0000-0002-5406-1963 \\ e-mail: natagor62@gmail.com
}

\begin{abstract}
The article deals with the problem of training future teachers (pre-school educators and speech therapists) for work with gifted children, and substantiates effective ways and methods of work with students in the process of teaching the discipline "Gifted Children Education". Particular attention is drawn to the problem of searching gifted children among the categories of children who are sometimes called special-needs children: children with sensorial or physical disabilities, developmental speech delays, etc. The author argues that the teacher or a speech therapist willingness to work with gifted children is determined by its theoretical knowledge and practical experience, which form a special personal adult's attitude to the gifted child. The teacher who works with the intellectually gifted children should have a professional and personal qualities, such as positive self-concept, selfconfidence, maturity and emotional stability, advanced intelligence and wide circle of interests, non-traditional personal ideology etc. The author argues that the main pedagogical condition for the preparation of future educators and speech therapists to work with gifted preschoolers is using of interactive learning methods in higher education. The author points out that traditional lectures are falling to meet the demand of students, so they should be interactive to ensure the active participation of students in the learning process. In particular, the lecture can be taken the form of interactive discussion, a multimedia presentation, etc. Examples of using interactive learning methods during lectures and workshops are described. Work on the multimedia project "Life of Outstanding Children" will also be facilitated by the development of the future pre-school educators and speech therapists creativity. Also, the article analyzes some concepts of cleverness, future teachers should get examine (concepts of J. Rensulli, P. Torrens).
\end{abstract}

Keywords: gifted, gifted child, pre-school teacher, speech therapist, self-concept, interactive teaching methods, lecture, mutual learning.

Стаття надійшла до редакиії 19.09.2019 p. 